\title{
Maternal mortality in the indigenous and non-indigenous population in Pará: contribution to the surveillance of deaths
}

\author{
Mortalidade materna na população indígena e não indígena no Pará: contribuição para a \\ vigilância de óbitos \\ Mortalidad materna en la población indígena y no indígena en Pará: contribución para el \\ control de óbitos
}

Deivid Ramos dos Santos ${ }^{1}$ Laura Maria Vidal Nogueira ${ }^{1}$

Bárbara Lopes Paiva ${ }^{1}$ Ivaneide Leal Ataide Rodrigues ${ }^{1}$

Lívia Félix de Oliveira ${ }^{1}$

Samantha Pereira Caldas ${ }^{1}$

1. Universidade do Estado do Pará.

Belém, Pará, Brazil.
Corresponding author:

Bárbara Lopes Paiva.

E-mail: barbaralopespaiva@gmail.com

Submitted on 06/04/2017.

Accepted on 08/28/2017.

DOI: 10.1590/2177-9465-EAN-2017-0161

\begin{abstract}
Objective: To analyze the occurrence of Maternal Mortality in general and in the indigenous population in the state of Pará Method: A quantitative, analytical and retrospective study was performed, covering a historical series from 2005 to 2014 . For the analysis of the results, non-parametric statistical tests, the Chi-square test and the $G$ test were processed in the BioStat 5.0 software program. Results: A total of 884 maternal deaths were reported in the state of Pará, corresponding to a Mortality Rate of 60.7 per 100,000 live births for non-indigenous women and 135.8 per 100,000 live births for indigenous women. Oedema, proteinuria and hypertensive disorders in pregnancy, childbirth and puerperium corresponded to $30.5 \%(n=270)$. Conclusion and implications for the practice: Maternal mortality remains a serious public health problem in the state of Pará, clearly demonstrating that indigenous pregnant women require greater care, since they showed higher Maternal Mortality Rates when compared to non-indigenous women.
\end{abstract}

Keywords: Maternal Mortality; Indigenous Population; Public Health Surveillance.

\section{Resumo}

Objetivo: Analisar a ocorrência da Mortalidade Materna na população geral e população indígena no estado do Pará. Método: Estudo com abordagem quantitativa, analítica, retrospectiva, abrangendo uma série histórica de 2005 a 2014. Para análise dos resultados, utilizou-se testes estatísticos não paramétricos, Qui-quadrado e teste G, processados no programa BioStat 5.0. Resultados: Foram notificados 884 óbitos maternos no estado do Pará, correspondendo a Razão de Mortalidade Materna de 60,7 por 100 mil nascidos vivos para as mulheres não indígenas e 135,8 por 100 mil nascidos vivos para as indígenas. Observou-se que o edema, a proteinúria e transtornos hipertensivos na gravidez, no parto e puerpério corresponderam a $30,5 \%(n=270)$. Conclusão e implicações para prática: Concluiu-se que a mortalidade materna ainda é um grave problema de saúde pública no Estado, demonstrando claramente que as gestantes indígenas requerem um maior cuidado, tendo em vista que apresentaram índices mais elevados na Razão de Mortalidade Materna se comparado às mulheres não indígenas.

Palavras-chave: Mortalidade Materna; População Indígena; Vigilância em Saúde Pública.

\section{Resumen}

Objetivo: Analizar los casos de Mortalidad Materna en la población general e indígena del estado de Pará. Método: Estudio con abordaje cuantitativo, analítico, retrospectivo, que abarca un historial de 2005 a 2014. Para analizar los resultados, se utilizaron pruebas estadísticas no-paramétricas, el Chi-Cuadrado y la prueba G, procesados en el programa BioStat 5.0. Resultados: Se pudo comprobar 884 óbitos maternos, correspondientes a la Razón de Mortalidad Materna 60,7 por 100 mil nacidos vivos de no indígenas y 135,8 de 100 mil nacidos vivos de indígenas. El edema, la proteinuria y los trastornos de hipertensión en el embarazo, parto y puerperio corresponden a 30,5\% $(n=270)$. Conclusión e implicaciones para la práctica: La mortalidad materna es aún un grave problema de salud pública en el estado, demostrando claramente que las indígenas requieren de una mayor atención, ya que presentaron índices más elevados de mortalidad materna si lo compara con no indígenas.

Palabras clave: Mortalidad Materna; Población Indigena; Control en Salud Pública. 


\section{INTRODUCTION}

Maternal Mortality ( $\mathrm{MM}$ ) continues to be a challenge to health, especially in developing countries, where women's care services are not fully effective. MM is an intrinsic indicator of the population's quality of life and it is considered to be a violation of human rights, mainly because it is a preventable tragedy in nearly $92 \%$ of cases, thus representing a public health issue. ${ }^{1-6}$

In light of this, themes connected to women's health and associated with the gestational period and MM have become more relevant in the international political context, especially after 2000, when the theme was the "Fifth Millennium Development Goal (MDG)". One of its objectives is the reduction in maternal mortality rate by $75 \%$ until $2015 .^{7}$

It is estimated that 1.5 million maternal deaths in 2000 and 2015 were prevented. Moreover, during this period, the MDG met some objectives globally, while others were only achieved by some countries. For 2016 and 2030, the Sustainable Development Goal (SDG) that will replace the MDG brought new objectives, among which the reduction in global maternal mortality rate to less than 70 deaths per 100,000 live births stood out. ${ }^{8,9}$

$\mathrm{MM}$ is characterized by the death of a woman during pregnancy or up to 42 days after its end, regardless of the gestational period, which can be caused by factors associated with or aggravated by the pregnancy itself or actions taken by the medical team. Furthermore, it can be divided into two groups: one with a direct obstetric cause - those that occur due to obstetric complications during pregnancy, childbirth or puerperium, due to interventions, neglect or inadequate treatment; and the other with an indirect obstetric cause - whose aggravating factors already existed before pregnancy. ${ }^{1,4,10}$

In developing countries, direct cause complications correspond to slightly more than two thirds of the overall MM rate, showing the low quality of obstetric care. In contrast, in developed countries, the situation is reversed. ${ }^{1,4}$

According to the World Health Organization (WHO), in 2005 , a total of 536,000 women died worldwide, victims of complications associated with the gestational-puerperal cycle, and only $15 \%$ of them were from developed countries. This confirms the fact that the magnitude of this problem mainly originates from developing countries, where prenatal, childbirth and puerperium care and follow-up are insufficient. ${ }^{10-12}$

Moreover, according to the $\mathrm{WHO}$, in 2013, 289,000 maternal deaths were estimated to have occurred worldwide. Although such number decreased nearly $45 \%$ when compared to 1990 , this figure remains high, as the majority of deaths would probably be preventable if universal access to health services had been guaranteed. ${ }^{13}$

Despite the increasing number of studies on this theme, the majority has originated from urban populations. This shows how partial the approach to this theme has been, especially in Brazil, a diverse country of continental proportions where there is a clear distinction between urban and rural populations. Moreover, another clearly observed bias is the fact that few epidemiological studies in this country consider the ethnicity, socioeconomic class and culture in which women are included. , $14,15^{\text {Countries }}$ where there is an economic, cultural, social and ethnic difference, studies dealing with such variables are essential, especially for a more detailed view of the context of occurrence of pregnancy.

According to data released by the Ministry of Health, between 1990 and 2010, in Brazil, there was a decrease in MM from 141 to 68 deaths per 100,000 live births, which represents a $51 \%$ reduction. Despite the developments observed, these data are not territorially homogeneous, not even according to socioeconomic and ethnic variables. ${ }^{1}$

In 2013, the Northern Region accounted for 232 maternal deaths in the overall population. However, in the state of Pará alone, there were 117 deaths, showing the lack of quality of care for women in the gestational-puerperal cycle. ${ }^{16}$ In 2010 , this state had a Maternal Mortality Rate (MMR) of 51.91 deaths per 100,000 live births, higher than what is recommended by the WHO, which established a rate of up to 20 deaths per 100,000 live births. ${ }^{13,17}$

Pará is still ranking high among all Brazilian states and, according to studies performed in metropolitan regions, there was not a significant reduction in MM throughout the years. This raises questions about the effectiveness of actions taken to reduce $\mathrm{MM}$ in this state as well as about political will. 2,18,19

In this context, indigenous women are included in a population group with the worst socioeconomic conditions, high fertility rates, early beginning of reproduction life and short inter-gestational periods. Thus, they require prenatal care follow-up, especially to identify and monitor cases of medium- to high-risk pregnancy and, consequently, to reduce birth complications and the ensuing maternal and fetal mortality. ${ }^{6}$

In light of this, the general objective of the present study was to analyze the occurrence of maternal mortality in the overall and indigenous populations, whereas the specific objectives were to identify the epidemiological and socio-demographic profile of maternal death in indigenous and non-indigenous women and to estimate the maternal mortality rate between indigenous and non-indigenous women.

It is important to become aware of regional particularities and different socio-epidemiological contexts of occurrences of maternal mortality, with the purpose of supporting the operationalization of health policies aimed at the improvement of service management and quality of women's care.

\section{METHODS}

The present study was developed with a quantitative, analytical and retrospective approach, performed from data on maternal mortality recorded in the Sistema de Informações sobre Mortalidade (SIM - Mortality Information System), which were made available by the Secretaria de Estado de Saúde Pública 
do Pará (SESPA - State of Pará Department of Public Health), in an electronic spreadsheet that highlights an event according to ethnicity - indigenous and non-indigenous, in a historical series of ten years corresponding to the 2005-2014 period. These data were added to other information about the number of live births (LB) available on the Ministry of Health's DATASUS website, aiming to calculate the MMR. ${ }^{16}$

The inclusion criteria were defined as records of MM of women aged ten to 49 years, living in the state of Pará, who died between January 2005 and December 2014, according to the criteria established by the World Health Organization (WHO), including their ethnicity.

Data were grouped in accordance with Chapter 15 of the ICD-10, covering the following groups: Pregnancy that ends in abortion; oedema, proteinuria and hypertensive disorders during pregnancy, childbirth and puerperium; other maternal disorders predominantly associated with pregnancy; health care provided to mothers for reasons associated with the fetus and amniotic cavity and for possible birth-related problems; complications during labor and birth; complications predominantly associated with puerperium; and other obstetric disorders not elsewhere classified.

The MMR was subsequently calculated, year by year, in the 2005-2014 historical series. Aiming to obtain better visualization, the cities in the state of Pará were grouped according to the regionalization established for health management. Thus, 144 cities were divided into 13 regions, in accordance with Resolution 0849 CIB-PA. Next, the specific MMR of each region as calculated, for both the indigenous and non-indigenous populations. All LB with unspecified ethnicity were excluded from this calculation and used to estimate the overall MMR of the state of Pará.

The data obtained were analyzed with the statistical nonparametric Chi-square and $G$ tests to express association between variables. The BioStat software program, version 5.0, was used with a $p$-value $<0.05$. Individual confidence intervals were constructed for the indigenous and non-indigenous populations and between the maternal mortality rates in these populations and, finally, confidence intervals were constructed for the "place of occurrence" variable, based on the proportion of cases. Confidence intervals of $95 \%$ were adopted in all calculations. The present study was approved by the Research Ethics Committee of the Undergraduate Nursing Course of the State of Pará University, under official opinion number 1348086.

\section{RESULTS}

Between 2005 and 2014, a total of 884 maternal deaths were reported among indigenous and non-indigenous women in the state of Pará, with an annual mean of 88.4 maternal deaths per year. Of these, $97.8 \%(n=865)$ corresponded to the non-indigenous population, with an annual mean of 86.5 cases. The indigenous population totaled only $1.5 \%$ of the deaths recorded $(n=13)$, with a mean of 1.3 cases per year. A total of six maternal deaths did not have the "ethnicity" variable completed and, as a result, were exclusively used to calculate the MMR of the total population.

According to Table 1, the highest frequency of maternal deaths in the population of this state was in 2013 , with $13 \%$ $(n=115)$ corresponding to an MMR of 82.5 per 100,000 LB, while the second highest frequency occurred in 2014, with $12.1 \%$ of deaths $(n=107)$. In contrast, the lowest frequency was found in 2009, with 74 maternal deaths, corresponding to $8.4 \%$, with an MMR of 51.70 per 100,000 LB. It should be emphasized that there was a significant increase in MMR in recent years during the study period.

In terms of maternal death in the indigenous population, 13 deaths were reported and the highest rates occurred in 2012 and 2013, with an MMR of 249.0 and 248.8 per 100,000 LB, respectively. In 2006 and 2011, there were no records of indigenous maternal deaths, characterizing a null MMR. The number of indigenous LB for the period considered was 9,575 , resulting in a MMR of 135.8 per 100,000 LB.

Regarding the non-indigenous population, a total of 865 maternal deaths were reported, with an MMR of 60.7 per 100,000 LB in the study period. The highest number of maternal deaths was found in 2013, totaling 110 cases (12.9\%) with an MMR of 80.4 per 100,000 LB. In contrast, the lowest MMR occurred in 2009 , with 51.4 per 100,000 LB, corresponding to $8.4 \%$ of cases $(\mathrm{n}=73)$ (Table 1).

When deaths were distributed according to Chapter 15 of the ICD-10, problems related to oedema, proteinuria and hypertensive disorders during pregnancy, childbirth and puerperium corresponded to $30.5 \%(n=270)$, followed by complications during labor $(n=194)$ and complications related to the puerperium $(n=149)$ (Table 2$)$.

According to Table $3,91.9 \%(n=812)$ of deaths occurred in a hospital environment, with similar values found for indigenous 92.3\% $(n=12)$ and non-indigenous women $91.8 \%(n=794)$.

Regarding the cause of maternal death in the non-indigenous population, $86.2 \%(n=746)$ had a record of direct obstetric death and $12.8 \%(n=110)$ had a record of indirect obstetric death. In contrast, in the indigenous population, the total number of deaths corresponded to direct obstetric causes.

Of all deaths, only $41.9 \%(n=370)$ had their investigation adequately recorded in the death report files, whereas $40.5 \%$ $(n=358)$ were not investigated. More care was provided to the indigenous population during this procedure, when compared to non-indigenous women.

When maternal deaths were distributed per health region, they were mainly concentrated in the Metropolitan Region 1 ( $n=$ $185)$, followed by the Carajás Region $(n=111)$, corresponding to $20.9 \%$ and $12.6 \%$, respectively, as observed in Table 4. Taking the indigenous population into consideration, $38.5 \%(n=5)$ were concentrated in the Xingu Region, which is far from the capital city and includes a considerable number of indigenous individuals. 


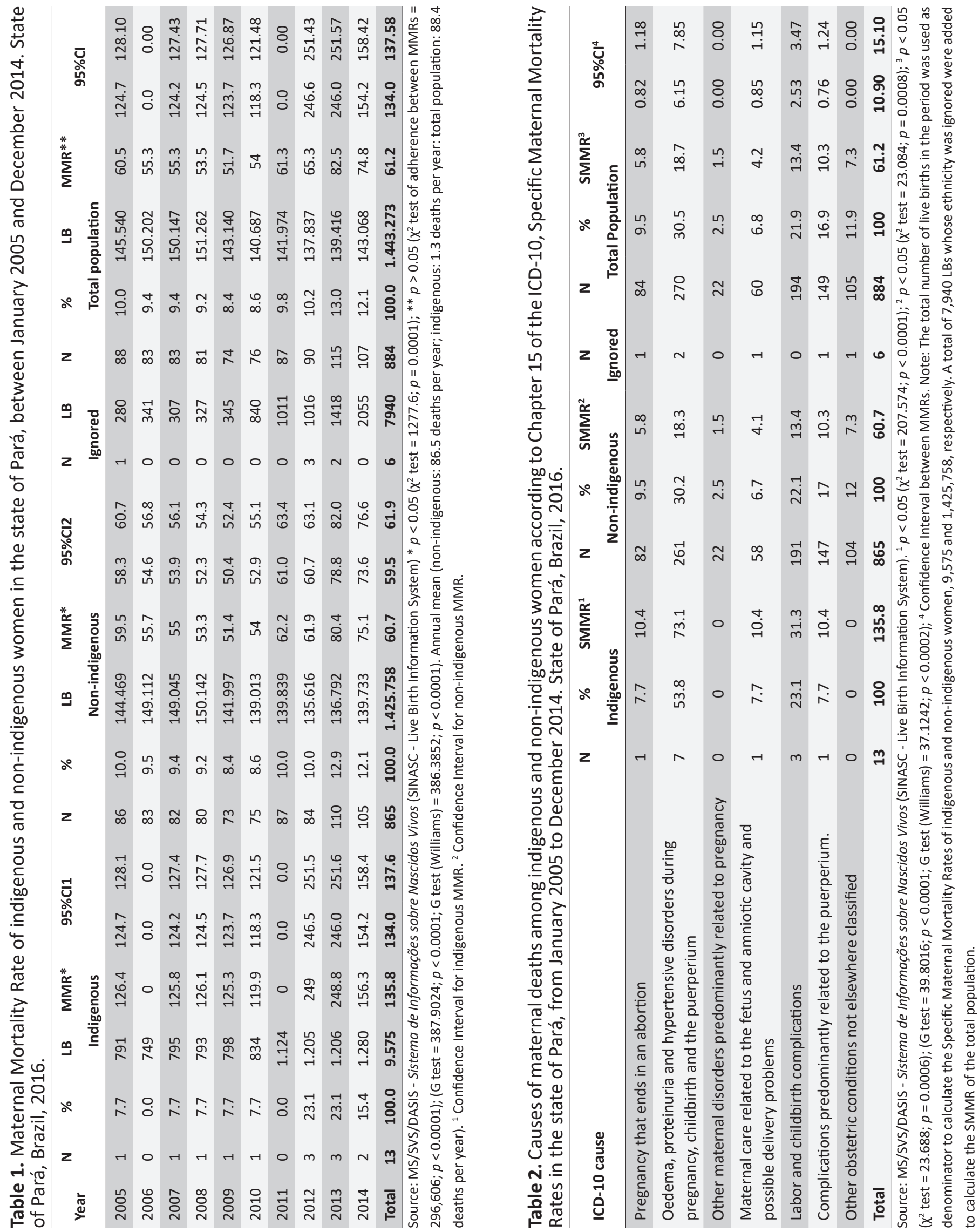


Table 3. Place of occurrence of maternal deaths between indigenous and non-indigenous women in the state of Pará, between January 2005 and December 2014. State of Pará, Brazil, 2016.

\begin{tabular}{|c|c|c|c|c|c|c|c|c|c|c|}
\hline \multirow[t]{2}{*}{ Variables } & \multicolumn{2}{|c|}{ Indigenous } & \multicolumn{2}{|c|}{ Non-indigenous } & \multicolumn{2}{|c|}{ Ignored } & \multicolumn{2}{|c|}{$\begin{array}{c}\text { Total } \\
\text { population }\end{array}$} & \multicolumn{2}{|c|}{$95 \% \mathrm{Cl}^{1}$} \\
\hline & $\mathbf{n}$ & $\%$ & $\mathbf{n}$ & $\%$ & $\mathbf{n}$ & $\%$ & $\mathbf{n}$ & $\%$ & & \\
\hline \multicolumn{11}{|l|}{ Place of occurrence } \\
\hline Hospital & 12 & 92.3 & 794 & 91.8 & 6 & 100 & 812 & 91.9 & 10.09 & 13.91 \\
\hline Other than hospital & 1 & 7.7 & 70 & 8.1 & 0 & 0 & 71 & 8.0 & 0.84 & 1.16 \\
\hline Ignored & 0 & 0 & 1 & 0.1 & 0 & 0 & 1 & 0.1 & 0.00 & 0.00 \\
\hline \multicolumn{11}{|l|}{ Obstetric cause } \\
\hline Direct obstetric maternal death & 13 & 100.0 & 746 & 86.2 & 4 & 66.7 & 762 & 86.2 & 11.07 & 14.93 \\
\hline Indirect obstetric maternal death & 0 & 0 & 110 & 12.8 & 2 & 33.3 & 113 & 12.8 & 0.00 & 0.00 \\
\hline Unspecified obstetric maternal death & 0 & 0 & 9 & 1.0 & 0 & 0 & 9 & 1.0 & 0.00 & 0.00 \\
\hline \multicolumn{11}{|l|}{ Investigated death } \\
\hline Investigated death with an informed death report file & 7 & 53.8 & 360 & 41.6 & 3 & 50.0 & 370 & 41.9 & 6.02 & 7.98 \\
\hline Investigated death without a death report file & 1 & 7.7 & 70 & 8.1 & 0 & 0 & 71 & 8.0 & 0.84 & 1.16 \\
\hline Death not investigated & 4 & 30.8 & 352 & 40.7 & 2 & 33.3 & 358 & 40.5 & 3.26 & 4.74 \\
\hline Not applicable & 1 & 7.7 & 83 & 9.6 & 1 & 16.7 & 85 & 9.6 & 0.82 & 1.18 \\
\hline Total & 13 & 100.0 & 865 & 100.0 & 6 & 100 & 884 & 100.0 & 10.92 & 15.08 \\
\hline
\end{tabular}

Source: MS/SVS/DASIS - Sistema de Informações sobre Nascidos Vivos (SINASC - Live Birth Information System). ${ }^{*} p>0.05$ (G test $=0.0328 ; p=0.9837 ; \mathrm{G}$ test (Williams) $=0.0049 ; p=0.9976) ;{ }^{1}$ Confidence interval between proportions. LB: live births; MMR: Maternal Mortality Rate.

\section{DISCUSSION}

MM is an extremely sensitive indicator of the quality of life of a population, as it refers to early preventable deaths that most often affect women with less access to social assets and it shows the lack of interaction and organization and low quality of health care provided to women during the gestational-puerperal cycle. ${ }^{20-22}$

Nonetheless, there are still great challenges that surpass individual analyses of each case and refer to a larger dimension, the population's reality of life, greatly influenced by the Brazilian reality, whose society is comprised of multiple cultures. Consequently, this context emphasizes the importance of studying factors associated with MM for the adequate formulation of strategies aimed at the reduction of this event. ${ }^{2,8,23-27}$

In the state of Pará, the MMR calculated from maternal deaths occurred between January 2005 and December 2014 was 61.2 deaths per 100,000 LB. This value is considered to be high, given the fact that the acceptable mean is from ten to 20 deaths per 100,000 LB. ${ }^{28}$ It should be emphasized that the MMR value of the total population does not differ greatly from the Brazilian mean, 69 maternal deaths per 100,000 LB. ${ }^{28}$ However, although these rates are similar, the Northern and Northeastern Regions continue to show the highest MMRs. ${ }^{26,29}$

There was not a great variation between 2005 and 2012, particularly between 2006 and 2010. In contrast, in the last two years, the MMR was high, 82.5 and 74.8 , respectively. This fact may have not been caused by the increase in maternal deaths in this region, but rather by the improvement in the reporting of deaths, as the denominator, LB, did not change significantly in the last years of this study.

The indigenous population's MMR was 2.4 times higher than that of the non-indigenous population. Additionally, the greatest difference was found in 2012, 4.02 times higher in the indigenous population, similar to the results found in the state of Mato Grosso. ${ }^{29}$ Although the indigenous population represents $1.5 \%$ of all maternal deaths in this state, such value is significant, because the total indigenous population comprises only $0.7 \%$ of the total (approximately 51,000). ${ }^{30}$ Difficulty to access basic and specialized health services, low quality of service and lack of professional training aimed at meeting specific risks to which indigenous women are exposed are the main reasons for this high rate. ${ }^{29}$

In terms of the distribution of deaths, according to Chapter 15 of the ICD-10, disorders associated with oedema, proteinuria and hypertensive disorders during pregnancy, childbirth and the puerperium (ICD 010-016) stood out when compared to others, equivalent to an absolute number of 270 (30.5\%) cases, similar to the results of other studies. ${ }^{31-34}$

Hypertensive diseases are predominantly found in this group. Childbirth complications, whose absolute number was 194 (ICD O60 - O75) and complications in the puerperium $(n=149)$ (ICD 085-092) also had a significantly high value. A similar result was found in a systematic review study that identified the main causes of maternal death, such as arterial hypertension, puerperal 


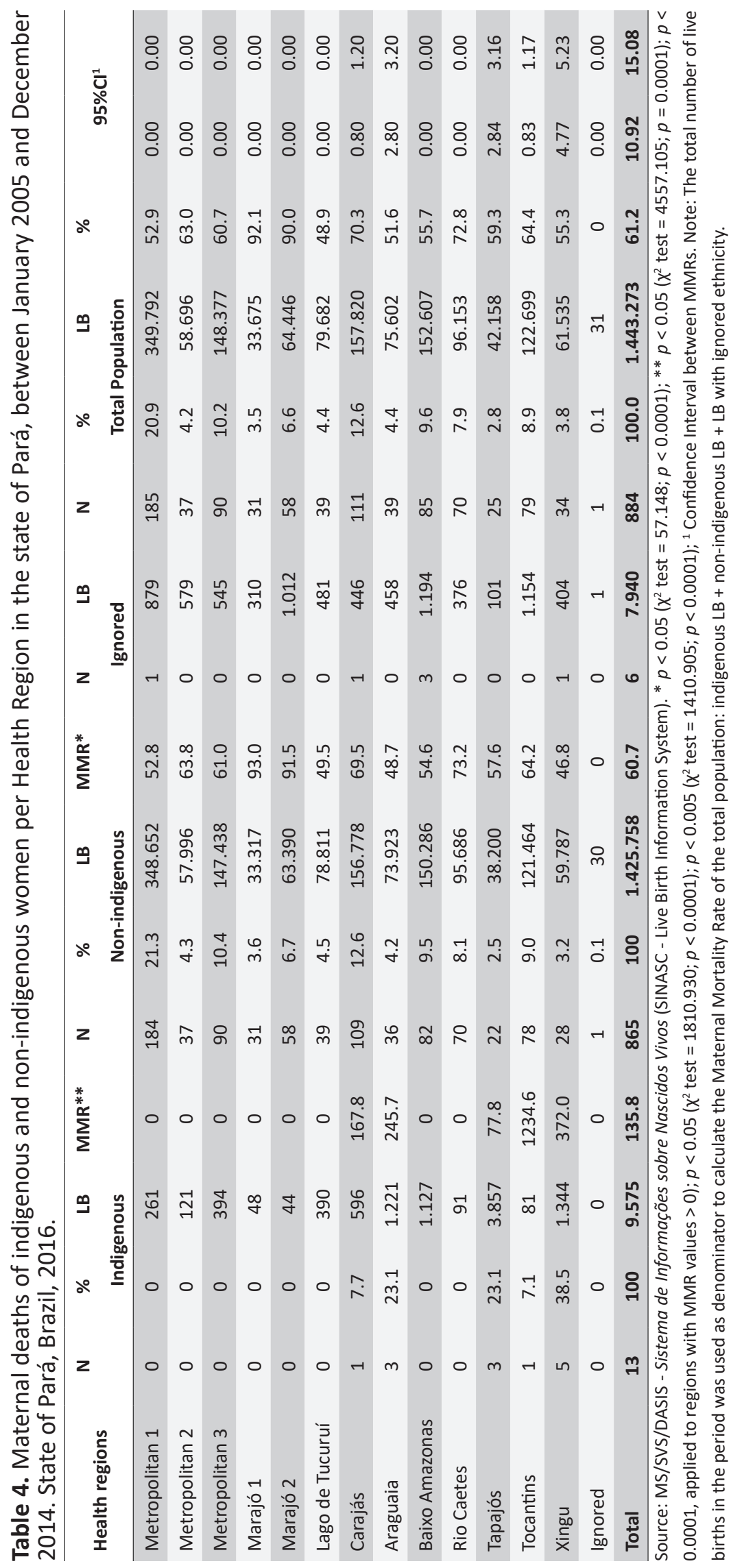


infection and hemorrhages. Additionally, the majority of studies on risk factors originated from Africa (29 articles), while Latin America totaled only $13.8 \%$ of articles following this approach. ${ }^{35}$

This result is in agreement with a study ${ }^{36}$ performed in Uganda, in which the specific severe maternal outcome rate was 9.37 per 1,000 LB for all hypertensive disorders. It could be concluded that there is high morbidity, attributed to hypertensive disorders during pregnancy. Researchers emphasized that certain complications associated with morbidity can be identified early. Thus, severe morbidity can be prevented through early intervention with childbirth, anti-hypertensive therapy and prophylactic treatment with magnesium sulfate.

This shows the real need for immediate actions of organizations and health to prioritize prenatal care, aiming to improve local health conditions, especially more vulnerable populations, because this can contribute to the detection of high-risk pregnancy and prevention of its complications, thus avoiding maternal death. ${ }^{3,8,13,17,37-40}$

There was a predominance $(86.2 \%)$ of maternal deaths due to direct obstetric causes - $100 \%$ in the specific case of the indigenous population -, thus confirming important remaining obstacles that prevent the reduction in MMR in the state of Pará, such as the lack of family planning and inadequate prenatal care. Regarding deaths due to indirect causes, overcrowding in referral hospital services, often found in larger regions exclusively, and structural deficiencies and lack of qualified personnel result in inadequate services provided to pregnant and puerperal women, thus causing maternal death. ${ }^{5}$

Comparing the maternal mortality rates in the state of Pará with those from other states, it is possible to identify two important points: underreporting and lack of information about this event in Pará. This is because studies performed in other regions, where states show a more developed socioeconomic standard and Comitês de Mortalidade Materna (CMM - Committees on Maternal Mortality) investigate maternal deaths, identified MMR as being higher than that found in the state of Pará, reflecting better surveillance on maternal deaths in these locations to the detriment of other regions. ${ }^{5,40-43}$

Moreover, according to a study ${ }^{44}$ conducted in the United States, pre-eclampsia should be dealt with and treated to prevent maternal and fetal deaths, as it is considered to be a severe pregnancy disorder that affects up to $8 \%$ of pregnant women in this country.

Of all deaths studied, only $41.9 \%$ were investigated according to what is recommended by the Health Policy. This shows the need for the implementation of measures to reduce MM in the state of Pará, through the identification of factors that trigger these deaths and the systematic investigation of maternal deaths by Committees on Maternal Mortality. ${ }^{8}$ It is an important measure to provide resources to prevent maternal deaths through the improvement of quality of pregnancy, childbirth and puerperium care in the various regions of this state.
The Marajó 1 and Marajó 2 Health Regions, which accounted for 92.1 and 90.0 maternal deaths per 100,000 LB, respectively, showed poorer living conditions and great difficulty to access health services due to geographic characteristics, as this is a riverside community. In this region, there were cities with the lowest human development indices in the country. ${ }^{30}$ It should be emphasized that there are distinct population characteristics and $43 \%$ of this population is covered by the Family Health Strategy, although being highly heterogeneous. Access to health services is frequently hindered by the fact that this is restricted to larger cities and it is insufficient.

Although the present study gives a wide perspective of MM in the state of Pará, the possible limitations of the present study refer to underreporting and/or incomplete data in the Sistema de Informações sobre Mortalidade (SIM - Information System on Mortality).

\section{CONCLUSIONS AND IMPLICATIONS FOR PRACTICE}

The present study enabled the identification of maternal mortality as a serious public health problem in the state of Pará, as the mean MMR value is very significant, especially in the indigenous population. MM affects young women with a low level of education and it has a significant occurrence in the hospital area with a predominance of direct causes. It should be emphasized that only $42 \%$ of all deaths were adequately investigated, showing that $\mathrm{MM}$ in this state is still not a priority theme, thus lacking further investigation.

Given this situation, it is essential to do whatever is possible to reduce the number of maternal deaths in the state of Pará, as they can be prevented by basic measures such as: higquality prenatal care, professional qualification, and improvement in service structure and coverage.

The need for more specific studies on the causes of maternal mortality and ethnic questions should be emphasized, so as to create and develop ways to reduce maternal mortality for more vulnerable groups.

Thus, primary health actions should be implemented during the gestational period, in view of the predominance of preventable deaths, especially in the indigenous population.

There was a high percentage of ignored data in the SIM for several variables, which shows the limitation of this information system. Thus, the record of data in these report databases in Brazil, especially in the state of Pará, is questionable, due to the lack of professional training. This fact causes individuals to fill out forms incorrectly, thus leading to low quality of information.

Despite these limitations, the information obtained from the present study can contribute to the development of strategies, aimed at the immediate reduction in MMR in the entire state. This would enable the focus to be aimed at priority areas requiring intervention, clearly showing that pregnant women, particularly indigenous ones in the state of Pará, need more care, based on the higher MMR values. 


\section{REFERENCES}

1. Ministério da Saúde (BR). Uma análise da situação de saúde e a vigilância da saúde da mulher. Brasília (DF): Ministério da Saúde;2012.

2. Botelho NM, Silva IFMM, Tavares JR, Lima LO. Causas de morte materna no Estado do Pará, Brasil. Rev Bras Ginecol Obstet [Internet]. 2014 Jul; [cited 2017 Jan 17]; 36(7):290-5. Available from: http://dx.doi. org/10.1590/SO100-720320140004892

3. Ferraz L, Bordignon M. Mortalidade materna no Brasil: uma realidade que precisa melhorar. Rev Baiana Saúde Pública [Internet]. 2012; [cited 2017 Jan 17]; 36(2):527-38. Available from: http://rbsp.sesab.ba.gov. br/index.php/rbsp/article/view/474

4. Ministério da Saúde (BR). Guia de vigilância epidemiológica do Óbito Materno. Brasília (DF): Ministério da Saúde; 2009.

5. Carreno I, Bonilha ALL, Costa JSD. Perfil epidemiológico das mortes maternas ocorridas no Rio Grande do Sul, Brasil:2004-2007. Rev Bras Epidemiol [Internet]. 2012 Jan; [cited 2017 Jan 17]; 15(2):396-406. Available from: http://dx.doi.org/10.1590/S1415-790X2012000200017

6. Marcolino DL. Saúde das mulheres indígenas no Brasil: uma revisão integrativa [Trabalho de conclusão de curso de graduação]. Porto Alegre (RS): Universidade Federal do Rio Grande do Sul; 2012.

7. United Nations. The Millennium Development Goals Report. 2014 [Internet]. New York: United Nations; 2014; [cited 2017 Jan 17]. Available from: http://www.un.org/millenniumgoals/2014\%20MDG\%20report/ MDG\%202014\%20English\%20web.pdf

8. United Nations. Sustainable Development Goals. 2015 [Internet]. New York: United Nations; 2015; [cited 2017 Jan 17]. Available from: https:// sustainabledevelopment.un.org

9. Souza PJ. A mortalidade materna e os novos objetivos de desenvolvimento sustentável (2016-2030). Rev Bras Ginecol Obstet [Internet]. 2015; [cited 2017 Jan 17]; 37(12):549-51. Available from: http://www. scielo.br/pdf/rbgo/v37n12/0100-7203-rbgo-37-12-00549.pdf

10. Ministério da Saúde (BR): Uma análise da situação e das doenças transmissíveis relacionadas à pobreza. Brasília (DF): Ministério da saúde; 2014.

11. Mota SMM, Gama SG, Theme Filha MM. A investigação do óbito de mulher em idade fértil para estimar a mortalidade materna no Município de Belém, Estado do Pará, Brasil. Epidemiol Serv Saúde [Internet]. 2009 Mar; [cited 2017 Jan 17]; 18(1):55-64. Available from: http://scielo.iec.pa.gov.br/scielo.php?script=sci_arttext\&pid=S167949742009000100006\&lng=pt\&nrm=iso

12. Xavier SB. Mortalidade materna em Pernambuco: uma revisão de literatura [Monografia]. Recife (PE): Departamento de Saúde Coletiva, Centro de Pesquisas Aggeu Magalhães, Fundação Oswaldo Cruz;2010.

13. World Health Organization. World Health statistics [Internet] Geneva; 2014. 180 p. [cited 2017 Sep 28]. Available from: http://apps.who.int/ iris/bitstream/10665/112738/1/9789240692671_eng.pdf

14. Chor D. Desigualdades em saúde no Brasil: é preciso ter raça. Cad Saúde Pública [Internet]. 2013 Jul; [cited 2017 Jan 17]; 29(7):1272-5. Available from: http://dx.doi.org/10.1590/S0102-311X2013000700002

15. Coimbra Jr. CEA, Garnelo L. Questões de Saúde Reprodutiva da Mulher Indígena no Brasil. In 2003. p. 1-26. [cited 2017 Sep 28]. Available from: http://www.cesir.unir.br/pdfs/doc7.pdf

16. Ministério da Saúde (BR). DATASUS.SVS4 Dashboard: Painel de Monitoramento da Mortalidade Materna. [cited 2017 Sep 27]. Available from: http://svs.aids.gov.br/dashboard/mortalidade/materna.show.mtw

17. Botelho NM, Silva IFMM, Tavares JR, Lima LO. Morte materna no estado do Pará: aspectos epidemiológicos. Rev. para. med [Internet]. 2013; [cited 2017 Jan 17]; 27(1). Available from: http://files.bvs.br/ upload/S/0101-5907/2013/v27n1/a3503.pdf

18. Mota SMM, Gama SGN, Theme Filha MM. Mortalidade materna no Município de Belém, Estado do Pará, em 2004: uma avaliação do Sistema de Informações sobre Mortalidade. Epidemiol Serv Saúde [Internet]. 2008 Mar; [cited 2017 Jan 17]; 17(1):33-42. Available from: http://scielo.iec.pa.gov.br/scielo.php?script=sci_arttext\&pid=S167949742008000100004\&lng=pt\&nrm=iso
19. Cordovil I. Hipertensão arterial na gravidez: aspectos práticos. Soc Bras Cardiol [Internet]. [cited 2017 Jan 17];2003;16(1). Available from: http://www.rbconline.org.br/artigo/hipertensao-arterial-na-gravidezaspectos-praticos/

20. Adomako J, Asare GQ, Ofosu A, lott BE, Anthony T, Momoh AS, et al Community-based surveillance of maternal deaths in rural Ghana. Bull World Health Organ [Internet]. 2016 Feb; [cited 2017 Jan 17]; 94(2):8691. Available from: https://www.ncbi.nlm.nih.gov/pubmed/?term=Ado mako+J\%2C+Asare+GQ\%2C+Ofosu+A\%2C+et+al.+Community-ba sed+surveillance+of+maternal+deaths+in+rural+Ghana

21. Dandona R, Pandey A, Dandona L. A review of national health surveys in India. Bull World Health Organ [Internet]. 2016 Apr; [cited 2017 Jan 17]; 94(2):286-96. Available from: https://www.ncbi.nlm.nih.gov/pubm ed/?term=Rakhi+D\%2C+Anamika+P\%2C+Lalit+Dandona.+A+review +of+national+health+surveys+in+India.+Bull+World+health+Organ

22. Nakimuli A, Nakubulwa S, Kakaire O, Osinde MO, Mbalinda SN, Nabirye $\mathrm{RC}$, et al. Maternal near misses from two referral hospitals in Uganda: a prospective cohort study on incidence, determinants and prognostic factors. BMC Pregnancy Childbirth [Internet]. 2016 Jan; [cited 2017 Jan 17]; 28(16):24. Available from: https://www.ncbi.nlm.nih.gov/pubmed/? term=Maternal+Near+Misses+from+Two+Referral+Hospitals+in+Uga nda $\% 3 \mathrm{~A}+\mathrm{A}+$ Prospective+Cohort+Study+on+Incidence\%2C+Determ inants+and+Prognostic+Factors

23. Barbastefano PS, Vargens OMDC. Prevenção da mortalidade materna: desafio para o enfermeiro. Rev Bras Enferm [Internet] 2009 Mar; [cited 2017 Jan 17]; 62(2):278-82. Available from: http://www.scielo.br/scielo. php?script=sci_arttext\&pid=S0034-71672009000200017\&lng=pt\&nrm =iso

24. Viana RC, Novaes MRCG, Calderon IMP. Mortalidade Materna - uma abordagem atualizada. Com Ciênc Saúde [Internet]. 2011; [cited 2017 Jan 17]; 22(Sup 1):141-52. Available from: http://bvsms.saude.gov.br/ bvs/artigos/mortalidade_materna.pdf

25. Programa das Nações Unidas para o Desenvolvimento no Brasil Objetivos de Desenvolvimento do Milênio. 3ํㅡㄹ Relatório Nacional de Acompanhamento;2007. Available from: http://www.pnud.org.br/ODM. aspx

26. Morse ML, Fonseca SC, Barbosa MD, Calil MB, Eyer FPC. Mortalidade materna no Brasil: o que mostra a produção científica nos últimos 30 anos? Cad Saúde Pública [Internet]. 2011 Apr; [cited 2017 Jan 17]; 27(4):623-38. Available from: http://www.scielo.br/scielo. php?script=sci_arttext\&pid=S0102-311X2011000400002\&Ing=en\&n rm=iso

27. Organização Mundial da Saúde (OMS). Relatório do Fórum de Mobilização pela Redução da Mortalidade Materna, Infantil e Fetal. 2013 [cited 2017 Jan 17]. Available from: file:///C:/Users/dell/ Downloads/relatorio-do-forum-de-mobilizacao-pela-reducao-da--[442040814-SES-MT].pdf

28. World Health Organization (WHO). Trends in Maternal Mortality: 1990 to 2013. Estimates by WHO, UNICEF, UNFPA, The World Bank and the United Nations Population Division. World Health Organization; 2014 [Internet]. [cited 2017 Jan 17]. Available from: http://apps.who.int/iris/ bitstream/10665/112682/2/9789241507226_eng.pdf?ua=1

29. Teixeira NZF, Pereira WR, Barbosa DA, Vianna LAC. Mortalidade materna e sua interface com a raça em Mato Grosso. Rev Bras Saúde Mater Infant. 2012;12(1):27-35.

30. Instituto Brasileiro de Geografia e Estatística (IBGE). População residente, segundo a situação do domicílio e condição de indígena Brasil 1991/2010 [Internet]. 2010; [cited 2015 Aug 9]. Available from: http://indigenas.ibge.gov.br/graficos-e-tabelas-2.html

31. Lindam A, Johansson S, Stephansson O, Wikström AK, Cnattingius S. High Maternal Body Mass Index in Early Pregnancy and Risks of Stillbirth and Infant Mortality-A Population-Based Sibling Study in Sweden. Am J Epidemiol [Internet]. 2016 Jul; [cited 2017 Jan 9]; 184(2):98-105. Available from: https://www.ncbi.nlm.nih.gov/pubme $\mathrm{d} /$ ?term=High+Maternal+Body+Mass+Index+in+Early+Pregnancy+a nd+Risks+of+Stillbirth+and+Infant+Mortality \%E2\%80\%94A+Popula tion-Based+Sibling+Study+in+Sweden 
32. Mwaniki MK, Baya EJ, Mwangi-Powell F, Sidebotham P. 'Tweaking' the model for understanding and preventing maternal and neonatal morbidity and mortality in Low Income Countries: "inserting new ideas into a timeless wine skin". BMC Pregnancy Childbirth [Internet]. 2016 Jan; [cited 2017 Jan 9]; 16:14. https://www.ncbi.nlm.nih.gov/pubmed/ ?term=Mwaniki+MK\%2C+Baya+EJ\%2C+Mwangi+PF\%2C+Sideboth am+P.+BMC+Pregnancy+Childbirth.+\%5BInternet\%5D2016+\%5Bcit ed+2017+Jan+9\%5D\%3B16\%3A14.+Available+from\%3A+doi\%3A1 0.1186\%2Fs 12884-016-0803-5

33. Ntambue AM, Malonga FK, Dramaix-Wilmet M, Ngatu RN, Donnen P. Better than nothing? maternal, newborn, and child health services and perinatal mortality, Lubumbashi, democratic republic of the Congo: a cohort study. BMC Pregnancy Childbirth [Internet].2016 Apr; [cited 2017 Jan 9]; 16:89. Available from: https://www.ncbi.nlm.nih.gov/pubmed/?t erm=Better+than+nothing $\% 3 \mathrm{~F}+$ maternal\%2C+newborn $\% 2 \mathrm{C}+$ and + ch ild+health+services+and+perinatal+mortality\%2C+Lubumbashi\%2C+ Democratic+Republic+of+the+Congo\%3A+a+cohort+study

34. Nascimento FM, Dantas MFS, Bezerra RLA, Nery IS. Perfil da mortalidade materna em maternidade pública de Teresina - PI, no Período de 1996 a 2000: uma Contribuição da Enfermagem. Esc Anna Nery [Internet]. 2007 Sep; [cited 2017 Jan 9]; 11(3):472-8. Available from: http://www.scielo.br/ scielo.php?script=sci_arttext\&pid=S1414-81452007000300012\&lng=en \&nrm=iso. http://dx.doi.org/10.1590/S1414-81452007000300012

35. Reis LGC. Eventos adversos durante o trabalho de parto e o parto em serviços obstétricos: desenvolvimento e aplicação de método de detecção [Dissertação]. Rio de Janeiro (RJ): Escola Nacional de Saúde Pública Sergio Arouca; 2012.

36. Nakimuli A, Nakubulwa S, Kakaire O, Osinde MO, Mbalinda SN, Kakande $\mathrm{N}$, et al. The burden of maternal morbidity and mortality attributable to hypertensive disorders in pregnancy: a prospective cohort study from Uganda. BMC Pregnancy Childbirth [Internet]. 2016 Aug; [cited 2015 Aug 9]; 16:205. Available from: https://www.ncbi.nlm.nih. gov/pubmed/?term=The+burden+of+maternal+morbidity+and+morta lity+attributable+to+hypertensive+disorders+in+pregnancy\%3A+a+pr ospective+cohort+study+from+Uganda
37. Gastaud ALGS. A mortalidade materna e a mortalidade infantil em Mato Grosso do Sul, Brasil, de 2000 a 2002. 2007 [Tese]. Campo Grande: Universidade Federal de Mato Grosso do Sul; 2007.

38. Souza FFB, Borges AKP, Silva DS, Yan L. Levantamento das doenças nos indígenas da ilha do Bananal, 2003-2013. In: 10 Seminário de Iniciação Científica da UFT; 2014 Nov 25-28; Palmas, TO, Brasil. 5 p.

39. Ferreira MEV, Matsuo T, Souza RKT. Aspectos demográficos e mortalidade de populações indígenas do Estado do Mato Grosso do Sul, Brasil. Cad Saúde Pública. 2011;27(12):2327-39.

40. Moran M. The Grand Convergence: Closing the Divide between Public Health Funding and Global Health Needs. PLoS Biol [Internet]. 2016 Mar; [cited 2017 Jan 9]; 14(3):e1002363. Available from: https://www. ncbi.nlm.nih.gov/pubmed/?term=Moran+M.+The+Grand+Convergenc e\%3A+Closing+the+Divide+between+Public+Health+Funding+and+G lobal+Health+Needs. doi: 10.1371/journal.pbio.1002363

41. Melo ECP, Knupp VMAO. Mortalidade materna no município do Rio de Janeiro: magnitude e distribuição. Esc Anna Nery. 2008;12(4):773-80.

42. Novo JLVG, Gianini RJ. Mortalidade materna por eclâmpsia. Rev Bras Saúde Mater Infant [Internet]. 2010 Apr; [cited 2017 Sep 27] 10(2):209-17. Available from: http://dx.doi.org/10.1590/S151938292010000200008

43. Souza J. Mortalidade materna e desenvolvimento: a transição obstétrica no Brasil. Rev Bras Ginecol Obstet [Internet]. 2013; [cited 2017 Sep 27] 35(12):533-5. Available from: http://www.scielo.br/pdf/rbgo/v35n12/01. pdf

44. Jenny LS, Robin LD. Preeclampsia, of mice and women. Physiologica Genomics. [Internet] 2016 Aug; [cited 2017 May 9]; 48(8):565-72. Available from: https://www.ncbi.nlm.nih.gov/pubmed/?term=Preec ampsia\%2C+of+mice+and+women.+Physiological+Genomics. DOI 10.1152/physiolgenomics.00125.201 